\title{
RESPON MUSLIMAH HIZBUTTAHRIR INDONESIA (MHTI) TERHADAP RANCANGAN DAN UNDANG-UNDANG TERKAIT PEREMPUAN DAN KELUARGA
}

\section{The Responses of Muslimah Hizbuttahrir Indonesia (MHTI) Towards The Drafts and The Laws Relating with Women and Family Ita Musarrofa}

\author{
Fakultas Syariah dan Hukum UIN Sunan Ampel \\ Jl. Ahmad Yani 117 Surabaya. \\ Email: itaisme@gmail.com
}

Naskah diterima tanggal 6 Mei 2015. Naskah direvisi tanggal 28 Mei 2015. Naskah disetujui tanggal 22 Mei 2015

\begin{abstract}
Abstrak
Penelitian ini merupakan kajian atas respon MHTI terhadap Rancangan Undang-Undang Hukum Materil Peradilan Agama (RUU-HMPA), Counter Legal Draft- Kompilasi Hukum Islam (CLDKHI), dan Undang-Undang Penghapusan Kekerasan Dalam Rumah Tangga (UU-PKDRT) dengan menggunakan teknik analisis wacana kritis. Data digali melalui pengumpulan dokumen atau teks respon MHTI dari situs resmi MHTI maupun dari booklet-booklet yang disebarkan MHTI. Setelah data terkumpul lalu dianalisis dengan analisis wacana kritis memakai model analisis Teun A. van Dijk, menggunakan tiga analisis sebagai satu kesatuan, yaitu: analisis teks wacana, analisis kognisi sosial serta analisis konteks wacana. Sedangkan teori-teori yang digunakan sebagai konstruk dalam melihat praktik wacana oleh MHTI tersebut adalah teori Michel Foucault tentang pengetahuan dan kekuasaan serta teori Pierre Bourdieu tentang kekerasan simbolik. Dari sudut pandang analisis wacana kritis, apa yang dilakukan MHTI merupakan bagian dari pertarungan wacana yang melibatkan praktik kekuasaan. Strategi kekuasaan yang digunakan dalam wacana MHTI dapat terlihat dari level teks, kognisi sosial dan konteks. Dilihat dari perspektif Michel Foucault tentang taktik kekuasaan, MHTI menjalankan ketiga taktik kekuasaan, yaitu taktik pemilahan, taktik normalisasi, taktik pendisiplinan atau panoptic. Ketiga taktik kekuasaan menurut Foucault tersebut senada dengan mekanisme sensorisasi dan eufimisasi dalam teori Bourdieu tentang kekerasan simbolik.Melalui wacana yang digulirkannya, khalayak digiring untuk meyakini bahwa sistem khilafah adalah satu-satu sistem yang bisa mengatasi segala persoalan bangsa dan satu-satunya sistem yang absah menurut Islam. Melalui mekanisme sensorisasi, MHTI membenturkan konsep-konsep keislamannya dengan konsep-konsep aktifis gender yang menurutnya berasal dari konsep kapitalis Barat yang memiliki agenda terselubung untuk menghancurkan umat Islam.
\end{abstract}

Kata kunci: MTHI, keluarga, RUU, perempuan

\section{Abstract}

The research is a study on the responses of Muslimah Hisbut Tahrir Indonesia (MHTI) towards the Draft for Material Law on Religious Court, Counter Legal Draft-Compilation of Islamic Law, and the Law on Elimination of Domestic Violence by using analytical discourse analysis. The data were obtained through the collection of documents or text responses of MHTI taken from the official website or from the booklets distributed by MHTI. The collected data were analyzed through the critical discourse analysis using analysis model of Teun A. Van Dijk, employing three analyses as a single entity: the discourse text analysis, social cognition analysis, and discourse context analysis. However, the theories used as spectacles in view of the practices of discourse by MHTI were Michel Foucault's theory about knowledge and power as well Pierre Bourdieu's theory about symbolic violence. From the standpoint of critical discourse analysis, what MHTI has done was the part of the battle discourse involving the power practices. The power strategy used in the MHTI discourse can be seen from the text level, social cognition, and context. Viewed from the 
Michel Foucault's perspective on power tactics, MHTI performs three tactics of power, namely classification practice, normalization tactics, disciplinary tactics or panoptic. The three power tactics of Foucault are in with sensorization mechanism and euphemism mechanism in Bourdieu's theory about symbolic violence. Through the discourse MHTI brought, people were taken to believe that the khilafah system is the one and the only system that is able to overcome all of the problems of the nation and the only system that is legal according to Islam. Through the sensorization MHTI bangs Islam concepts with activist gender concepts in which they think those came from west capitalist having covert agenda to destroy muslims .

Keywords: MTHI, family, Bill's law petition, pertaining to women

\section{PENDAHULUAN}

$\mathrm{P}$ erbedaan pendapat dalam kehidupan berbangsa dan bernegara adalah hal yang niscaya. Karena perbedaan pandangan ini, muncullah kelompok-kelompok atau organisasi yang didirikan untuk membumikan pendapat masing-masing. Setiap kelompok kemudian berusaha mengajak sebanyak mungkin orang untuk menyetujui bahkan menjadi anggota yang loyal pada kelompok dengan keyakinan-keyakinan yang diusungnya.

Untuk dapat memasarkan visinya, setiap kelompok memiliki strategi-strategi tertentu yang menjadi misi organisasi. Salah satu strategi yang digunakan adalah melalui strategi wacana. Membumikan visi organisasi melalui wacana, tidak hanya urgen untuk memperkenalkan organisasi keluar tetapi juga untuk mendisiplinkan anggota di dalam agar berperilaku sesuai dengan tata aturan organisasi. Dengan demikian, praktik wacana sangat terkait dengan kepentingan si pembuat wacana karena ia tidak sekedar berfungsi menyampaikan pesan tetapi juga memperjuangkan kepentingan. Wacana bahkan digunakan untuk tujuan mempengaruhi, merekayasa, menundukkan, serta mendisiplinkan pikiran dan tindakan orang lain.

Nama Hizbut Tahrir tidak lagi asing di telinga kita, selain karena pengikutnya yang semakin banyak terutama dari kalangan civitas akademik kampus-kampus besar, aksi-aksi damai serta publikasi yang sering dilakukan membuat namanya terus diberitakan dan semakin dikenal luas masyarakat tanah air. Organisasi yang berdiri pada tahun 1953 di Al-Quds, Palestina ini memiliki visi membimbing umat untuk mendirikan kembali sistem khilafah dan menegakkan hukum yang diturunkan Allah. Ia menyatakan dirinya sebagai organisasi politik yang berideologikan Islam: memperhatikan urusan-urusan umat dan mencari pemecahan yang sesuai dengan hukum Islam. Hizbut Tahrir juga memiliki visi mendidik dan membina umat serta membebaskan mereka dari akidah-akidah yang rusak, pemikiran-pemikiran yang salah, persepsi-persepsi yang keliru serta dari pengaruh ide-ide kufur (http://hizbut-tahrir.or.id/ tentang-kami/ diakses tanggal 30 Maret 2013).

Misi politik Hizbut Tahrir yang diistilahkan dengan ash siro'ulfikri (pertarungan pemikiran) dan kifahussiyasi (perjuangan politik) diwujudkan melalui penentangan terhadap ide-ide, hukumhukum dan perundang-undangan yang mereka pandang kufur dengan cara menjelaskan ketentuan hukum Islam dalam masalah tersebut. Mereka juga menentang dominasi negara imperialis dengan cara membebaskan umat dari pola pikir, kebudayaan, ekonomi, dan politik Barat (http://hizbut-tahrir. or.id/tentang-kami/ diakses tanggal 30 Maret 2013).

Visi yang dimiliki Hizbut Tahrir ini juga menjiwai kaum perempuan yang telah menjadi bagian dari perjuangan Hizbut Tahrir. Kaum perempuan ini membentuk wadah tersendiri agar bisa mengaktualisasikan perannya dalam menjalankan visi Hizbut Tahrir. Keinginan untuk menjadi organisasi otonom ini direspon dengan baik oleh pimpinan organisasi sehingga pada tahun 2000-an dibentuklah Muslimah Hizbut Tahrir Indonesia atau disingkat MHTI (untuk selanjutnya disebut MHTI).

Visi MHTI dalam mengarahkan dan membentuk kesadaran perempuan Islam Indonesia akan hak dan kewajibannya sesuai syariat Islam diwujudkan melalui penyelenggaraan trainingtraining, diskusi-diskusi di kampus dan masjidmasjid, melalui publikasi serta aksi-aksi damai. Selain itu, MHTI juga kerap melancarkan kritik kepada kebijakan pemerintah yang terkait dengan kebijakan yang menurut mereka tidak sesuai dengan 
yang digariskan Islam mengenai hak dan kewajiban perempuan.

Salah satu kebijakan pemerintah yang terkait dengan perempuan dan keluarga adalah rencana amandemen KHI dengan CLD-KHI (Counter Legal Draft-Kompilasi Hukum Islam) yang digagas oleh kelompok feminis. MHTI menilai, bahwa jika kebijakan ini dikabulkan, maka akan menghancurkan fikih keluarga dan keluarga muslim. Selain CLD-KHI, UU PKDRT (Undang-Undang Penghapusan Kekerasan dalam Rumah Tangga) tidak luput dari kritik MHTI. Undang-undang ini dipandang sebagai upaya penghancuran keluarga karena menggunting ketaatan istri terhadap suami (http://hizbut-tahrir.or.id/2011/10/30/nikah-dinipenyebab-kdrt/ diakses tanggal 30 Maret 2013). Peraturan lainnya yang menjadi sasaran kritik MHTI adalah RUU HMPA (Rancangan UndangUndang Hukum Materil Peradilan Agama) yang dianggap mengharamkan sesuatu yang dihalalkan oleh Allah, serta beberapa undangundang lainnya seperti undang-undang tentang perlindungan anak, amandemen undang-undang kesehatan (aborsi) serta undang-undang traficking dan kewarganegaraan (http://hizbut-tahrir. or.id/2010/03/01/pandangan-muslimah-terhadapnikah-siri/ diakses tanggal 30 Maret 2013).

Apa yang dilakukan pemerintah melalui rancangan undang-undang maupun undangundang yang telah disahkan tersebut, menurut MHTI merupakan upaya terselubung liberalisasi keluarga Islam yang masuk melalui lembaga internasional untuk menekan negeri-negeri muslim agar meratifikasi konvensi-konvensi yang sarat agenda liberal. MHTI meyakini adanya skenario kafir-penjajah Barat untuk menghancurkan keluarga Islam melalui agen-agennya di negara-negara muslim. Agen-agen inilah menurut mereka yang berupaya melakukan liberalisasi melalui penetapan perundang-undangan (http://www.khabarmuslim. com/tag/nikah-siri diakses tanggal 30 Maret 2013).

Sebagai sebuah wacana (discourse), kritik dan penolakan MHTI terhadap berbagai kebijakan pemerintah tersebut tidak muncul dari ruang hampa, tetapi berangkat dari upaya MHTI untuk menggiring kesadaran masyarakat Islam, terutama kaum perempuan agar berfikir dan berperilaku menurut tuntunan Islam sebagaimana penafsiran dan pemahaman MHTI. Melalui wacana liberalisasi keluarga di atas, MHTI juga membenturkan konsep Islam dengan konsep Barat dan memperhadapkan secara diametral feminisme dengan Islam.
Apa yang disampaikan MHTI melalui serangkaian tulisan yang menanggapi rencana dan kebijakan pemerintah terkait keluarga merupakan bagian dari misi MHTI dalam ash siro' al-fikri (pertarungan pemikiran) dan kifah-alsiyasi(perjuangan politik). Misi ini dilakukan untuk menyebarkan ideologi MHTI yang mereka yakini sebagai kebenaran.

Kedua misi yang dilakukan MHTI untuk menolak kebijakan pemerintah tersebut melibatkan strategi wacana yang digunakan agar ideologi yang mereka yakini dapat diterima dengan baik oleh masyarakat terutama kalangan wanita. Wacana yang digulirkan juga dimaksudkan sebagai perlawanan atas wacana kelompok lain yang juga telah berkembang di masyarakat, yaitu wacana keadilan dan kesetaraan terhadap perempuan yang diusung kalangan feminis.

Tulisan ini bermaksud melihat seperti apa pertarungan wacana yang terjadi mengenai perempuan dan keluarga di Indonesia melalui perlawanan wacana yang dilakukan oleh MHTI. Wacana yang digulirkan MHTI bukan hanya fenomena kebahasaan semata, tetapi juga praktik diskursif terencana yang digunakan untuk mensosialisasikan ideologi yang diyakini ke tengahtengah masyarakat, terutama kalangan perempuan Islam, sebagai tandingan ideologi feminis.

Telah ada beberapa penelitian yang mengkaji Hizbut Tahrir maupun Muslimah Hizbut Tahrir secara khusus. Penelitian terdahulu tersebut tidak hanya menginspirasi tetapi juga menjelaskan orisinalitas tulisan ini. Penelitian yang dilakukan oleh Erni Isnaeniyah yang berjudul "Gerakan Tandingan Feminisme (Tinjauan terhadap Respon Muslimah Hizbut Tahrir Indonesia Kota Bandung)" mengkaji tentang respon MHTI kota Bandung terhadap keberadaan organisasi feminis. Penelitian ini menemukan bahwa MHTI memandang gerakan yang bertentangan dengan syariat Islam dan hukum Allah SWT adalah batil dan haram hukumnya untuk diikuti, salah satunya adalah feminisme. Semua produk feminisme adalah haram diikuti karena feminisme adalah produk dari peradaban dan kebudayaan Barat. Barat adalah "musuh" Islam terbesar disebabkan Barat telah menghancurkan peradaban Islam secara terarah dan terus menerus sampai saat ini (Erni Isnaeniah, 2009).

Penelitian yang dilakukan M. Anas Kholis yang berjudul "Regulasi Poligami dalam UndangUndang RI No.1/1974 dan Kompilasi Hukum Islam: Studi Konstruksi Sosial Muslimah Hizbut Tahrir 
Indonesia" mengkaji tentang konstruksi pemikiran MHTI tentang poligami. Dengan menggunakan teori konstruksi sosial Peter L. Berger, penelitian ini mengkaji sebab-sebab MHTI menolak semua hal yang datang dari Barat termasuk regulasi poligami dalam Undang-Undang RI No.1/1974 (M. Anas Kholis, 2007).

Selain kedua penelitian terhadap MHTI di atas, telah dilakukan pula beberapa penelitian tentang HTI yang mengkaji ideologi HTI sebagai gerakan fundamentalis. Penelitian tersebut misalnya yang dilakukan oleh Syamsul Arifin dengan judul "Ideologi dan Praksis Gerakan Sosial Kaum Fundamentalis: Pengalaman Hizb al-Tahrir Indonesia". Penelitian ini mengkaji ideologi gerakan Hizbut Tahrir yang dinilai sebagai gerakan fundamental anti kekerasan dalam mewujudkan ideologinya (Syamsul Arifin, 2005).

Disertasi Umi Sumbulah juga mengkaji HTI dengan judul "Islam Radikal" dan Pluralisme Agama: Studi Konstruksi Sosial Aktivis Hizbut Tahrir dan Majelis Mujahidin Indonesia di Malang tentang Agama Kristen dan Yahudi". Dalam penelitiannya ini, Umi Sumbulah mengkaji konstruksi sosial aktivis Hizbut Tahrir dan Majelis Mujahidin di Malang tentang gagasan pluralisme agama, agama Kristen dan Yahudi, Kekerasan agama, Islam liberal serta relasi mereka dengan non-muslim (Umi Sumbulah, 2007).

Temuan beberapa penelitian di atas sangat menginspirasi penulis untuk melihat lebih jauh strategi wacana yang digunakan oleh MHTI dalam mensosialisasikan ideologinya dengan mendefinisikan diri dan organisasi lain, baik yang dilakukan secara terang-terangan maupun yang terselubung, menjelaskan bagaimana MHTI menolak rencana dan kebijakan pemerintah terkait keluarga, melihat alasan-alasan dan argumentasi yang dikemukakan, akan membongkar strategi wacana yang digunakan oleh MHTI dalam mengkritik dan menolak rencana dan kebijakan pemerintah. Mengetahui adanya berbagai pandangan, terutama dari pergerakan-pergerakan perempuan, akan memperkaya pengetahuan tentang apa sebenarnya yang diinginkan kaum perempuan sesuai dengan hukum yang hidup di masyarakat serta alasan-alasan di balik perbedaan pandangan tersebut. Selain itu, dengan mengetahui respon, terutama dari organisasi perempuan terhadap rancangan dan undang-undang tentang perempuan dan keluarga, akan dapat diprediksi efektivitas undang-undang ini di kalangan perempuan sendiri maupun masyarakat secara umum, baik yang sudah disahkan maupun yang masih berupa rancangan.

\section{METODE PENELITIAN}

Penelitian ini termasuk penelitian pustaka (library research). Data penelitian ini adalah respon MHTI terhadap rancangan dan undang-undang tentang perempuan dan keluarga, yaitu RUU HMPA, RUU CLD-KHI serta UU PKDRT. Respon tersebut berupa pemberitaan, artikel dan wawancara terhadap tokoh MHTI yang digali dari beberapa sumber resmi MHTI, yaitu: booklet-booklet MHTI dan situs resmi Hizbut Tahrir Indonesia, yaitu http://hizbut-tahrir.or.id. Data yang diperoleh dari sumber-sumber tersebut menjadi data primer. Data-data sekunder diperoleh dari buku-buku resmi HTI, yaitu: Nizhamul Islam (Peraturan Hidup dalam Islam), Nizhamul Ijtima'iy fi al-Islam (Sistem Pergaulan dalam Islam), Mafahim Hizbut Tahrir (Pokok-pokok Pikiran Hizbut Tahrir), Syakhshiyah Islamiyah - 3 jilid (Membentuk Kepribadian Islam).

Teknik yang digunakan dalam mengumpulkan data adalah dokumentasi. Setelah teks-teks respon MHTI terkumpul, kemudian dianalisis menggunakan teknik analisis wacana kritis (Critical Discourses Analysis). Dari beberapa model analisis wacana kritis yang kembangkan oleh para pemikir, penulis akan menggunakan teknik analisis yang digagas oleh Teun A. van. Dijk karena model analisis wacana kritis Teun A. van Dijk dinilai lebih jernih dalam merinci struktur, komponen dan unsurunsur wacana (Eriyanto, 2001: 342-356). Model analisis wacana kritis yang ditawarkan oleh Teun A. van Dijk dikenal dengan model kognisi sosial. Van Dijk menganggap bahwa penelitian atas wacana tidak cukup hanya didasarkan pada analisis tentang teks semata, karena teks hanya hasil dari suatu praktek produksi yang juga harus diamati. Maka harus dilihat juga bagaimana suatu teks diproduksi sehingga diperoleh suatu pengetahuan mengapa teks bisa semacam itu (Teun A. van Dijk, http:// www.daneprairie.com. Diakses tanggal 13 Pebruari 2006).

Menurut van Dijk, wacana mempunya tiga dimensi, yaitu: teks, kognisi sosial dan konteks, ketiganya harus digabungkan ke dalam satu kesatuan analisis sebagaimana skema berikut (Teun A. van Dijk,1988: 29-30): 
Gambar 1 : Kesatuan Analisis Teks, Kognisi Sosial dan Konteks

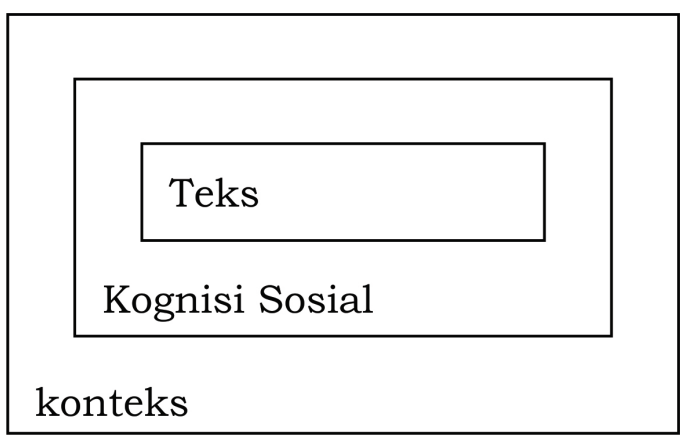

Sumber :Teun A. van Dijk,1988: 29-30

Teks menurut Teun A. van Dijk terdiri dari tiga struktur, yaitu:

1. Struktur makro (macro structure) yang menunjuk pada makna keseluruhan (global meaning) yang dapat dicermati dari tema atau topik yang diangkat oleh suatu wacana (Teun A. van Dijk, 1988: 31-35).

2. Struktur supra (superstructure) menunjuk pada kerangka suatu wacana atau skematika, seperti kelaziman percakapan atau tulisan yang dimulai dari pendahuluan, dilanjutkan dengan isi pokok, diikuti oleh kesimpulan, dan diakhiri dengan penutup. Bagian mana yang didahulukan, serta bagian mana yang dikemudiankan, akan diatur demi kepentingan pembuat wacana (Teun A. van Dijk, 1988: 49-53).

3. Struktur mikro (microstructure) menunjuk pada makna setempat (local meaning) suatu wacana. Ini dapat digali dari aspek semantik, sintaksis, stilistika, dan retorika (Teun A. van Dijk, 1988: 64-94).

Tidak cukup meneliti pada level teks, Teun A. van Dijk mengharuskan pemahaman terhadap kognisi pembuat teks untuk bisa mengetahui bagaimana suatu wacana diproduksi. Yang ia maksudkan dengan kognisi sosial adalah kesadaran mental pembuat teks yang berupa kepercayaan, pengetahuan dan prasangkanya. Analisis terhadap kognisi pembuat teks berangkat dari asumsi bahwa teks pada dasarnya dihasilkan lewat kesadaran, pengetahuan, prasangka, dan pengetahuan tertentu tentang suatu peristiwa. Terdapat suatu skema/ model yang digunakan dalam memandang sesuatu yang direpresentasikan dalam teks yang dapat berupa skema person (person schemas), yaitu bagaimana seseorang memandang orang lain, skema diri (self schemas), yaitu bagaimana seseorang memandang dirinya sendiri, skema peran (role schemas), yaitu bagaimana seseorang menggambarkan posisi atau peran yang ditempati seseorang dalam masyarakat, dan skema peristiwa (event schemas), yaitu bagaimana seseorang menafsirkan peristiwa dalam skema tertentu (Teun A. van Dijk, 1988: 49-52).

Penelitian ini melihat bagaimana skema MHTI dalam memandang kelompok feminis serta bagaimana MHTI mendefinisikan kelompoknya sendiri. Dilihat juga bagaimana MHTI memandang peran dan posisi perempuan dalam masyarakat serta bagaimana MHTI memandang peristiwa pembuatan dan pengesahan undang-undang yang terkait perempuan dan keluarga. Skema-skema yang digunakan dalam menghasilkan teks wacana oleh MHTI tersebut, tidak muncul begitu saja tetapi hasil dari pengaruh konteks sosial tempat setiap anggota MHTI menjalani pendidikan dan pembinaan serta bagaimana pandangan masyarakat secara umum mengenai peran dan posisi perempuan dalam struktur sosial masyarakat. Selain menggunakan teknik analisis wacana kritis Teun A. van Dijk, praktik wacana yang dilakukan MHTI akan dilihat pula menggunakan teori pengetahuan dan kekuasaan Michel Foucault dan teori kekerasan simbolik Pierre Bourdieu.

\section{PEMBAHASAN}

Respon Muslimah Hizbut Tahrir Indonesia terhadap Rancangan dan Undang-Undang Terkait Perempuan dan Keluarga

Respon MHTI terhadap RUU HMPA, CLDKHI dan UU PKDRT dalam situs tersebut, penulis mengkategorikannya dalam dua respon, yaitu: respon yang langsung pada RUU HMPA, CLD-KHI dan UU PKDRT serta respon yang berupa tanggapan terhadap upaya liberalisasi keluarga meskipun tidak secara langsung menyebut RUU HMPA, CLD-KHI dan UU PKDRT.

Dalam wacana yang digulirkan Muslimah Hizbut Tahrir, penulis mengkaji dua hal yang direpresentasikan melalui teks oleh MHTI, yaitu: pertama, representasi terhadap upaya amandemen undang-undang perkawinan terkait perempuan dan keluarga yang difokuskan pada RUU HMPA dan CLD-KHI serta undang-undang yang telah disahkan yaitu UU PKDRT. Kedua, representasi MHTI terhadap penggagas upaya amandemen tersebut.

1. Representasi MHTI terhadap Upaya Amandemen Undang-Undang Terkait Perempuan dan Keluarga

Ada beberapa istilah yang digunakan Muslimah Hizbut Tahrir dalam merepresentasikan upaya-upaya amandemen terhadap undang-undang 
yang berkaitan dengan perempuan dan keluarga yang diajukan kalangan feminis kepada pemerintah melalui jalur legislasi nasional. Istilah-istilah tersebut dijelaskan berikut ini:

a. Liberalisasi hukum Islam

MHTIdalam berbagai berita sertaartikel dalam situs resminya, seringkali menggunakan istilah liberalisasi hukum Islam terutama hukum keluarga, untuk mengkritik upaya-upaya yang dilakukan feminis dan pemerintah untuk mengamandemen undang-undang terkait perempuan dan keluarga baik itu RUU HMPA, CLD-KHI ataupun UU PKDRT. Sebagimana ditulis dalam sebuah berita tentang penyelenggaraan acara forum kajian tokoh muslimah yang dihadiri oleh Neng Djubaedah dan Najmah Saidah sebagai narasumber. Berikut ini dikutip komentar Najmah Saidah yang merupakan wakil dari Dewan Pengurus Pusat MHTI:

Najmah menyampaikan keluarnya HMPA bukan tanpa sebab. Di dalamnya terdapat ruh dan nuansa liberalisasi, yaitu CLD-KHI." Ini merupakan upaya terselubung liberalisasi keluarga. Tatanan keluarga terus digoyang merupakan bagian dari penjajahan global oleh musuh-musuh Islam (AS) yang menginginkan hancurnya tatanan kehidupan keluarga muslim," ujar Ibu Najmah. Skenario global ini secara sistematis dan struktural masuk melalui lembaga Internasional (PBB), yang menekan negeri-negeri muslim jajahan untuk meratifikasi konvensi-konvensi yang sarat agenda liberal seperti CEDAW dll.

Selanjutnya, negara menekan masyarakat dengan UU liberal yang dibuat dan diimplementasikan dalam bentuk program melalui Menteri Negara Pemberdayaan Perempuan (Meneg PP) hingga level masyarakat bawah yaitu posyandu. "Liberalisasi keluarga pun dilakukan secara kultural melalui program aksi LSM gender yang menggiring masyarakat seolah mereka menginginkan perubahan-perubahan hukum," tandas Ibu Najmah. Kalangan LSM pun saat ini gencar melakukan liberalisasi kepada para para ulama. Karena posisi strategis ulama di tengah masyarakat. Beliau pun menambahkan bahaya upaya liberalisasi keluarga berujung pada liberalisasi bangsa (http://hizbut-tahrir. or.id/2009/04/06/ada-upaya-sistemastisuntuk-meliberalkan-uu-perkawinan/, diakses 2 Desember 2013).

b. Menggugat dan mengubah hukum Allah
Upaya amandemen tersebut juga dinilai MHTI menggugat dan mengubah hukum Allah. Berikut ini kutipan pemberitaan dalam situs resmi MHTI:

Ibu Ratu Erma dari DPP MHTI menyampaikan kritiknya bahwa menjadikan pencatatan sebagai suatu kewajiban merupakan upaya merubah hukum Allah. Karena hukum pencatatan di dalam Islam adalah mubah termasuk aspek administratif saja." Ketika kaum liberal mewajibkan pencatatan, mereka telah menjadikan fakta sebagai sumber hukum (http://hizbut-tahrir.or.id/2009/04/06/adaupaya-sistemastis-untuk-meliberalkan-uuperkawinan/, diakses 2 Desember 2013).

Dalam media booklet yang disebarkan HTI juga dijelaskan bahwa:

Dalam UU PKDRT ini terkandung pasal-pasal yang mengugat pelaksanaan hukum syariat. Sebagai realisasi dari Konferensi Beijing (4/9/1995), definisi kekerasan, cara pandang dan pengaturan kehidupan berumah tangga didasarkan pada konvensi tentang Penghapusan Segala Bentuk Diskriminasi Terhadap Perempuan (Convention on the Elimination of All Form of Discrimination Againts women (CEDAW) serta mengacu pada langkah tindak yang telah ditetapkan dalam Konferensi Perempuan Sedunia ke-IV (Beijing Platform Action [BPFA]). Definisi kekerasan beranjak dari sudut pandang Barat (liberal). Akibatnya, banyak hal yang termasuk hukum syara' seperti mahar, sunat perempuan dan poligami dipandang sebagai bentuk kekerasan dalam rumah tangga (Hizbut Tahrir Indonesia, 2006: 7).

c. Mengharamkan yang dihalalkan Allah

Pernyataan mengenai hal ini misalnya sebagaimana dalam berita tentang penolakan HTI Bangka Belitung terhadap RUU Hukum Materi Peradilan Agama bidang perkawinan. Dalam berita ini ditulis komentar Ayik Hariansyah, humas Hizbut Tahrir Indonesia Bangka Belitung yang mengatakan bahwa:

HTI sangat tegas sekali menolak RUU tersebut, karena bertentangan dengan syariat Islam. Dalam hal iniberartipemerintah mengharamkan yang dihalalkan oleh Allah SWT," tegas Ayik (http://hizbut-tahrir.or.id/2009/04/06/adaupaya-sistemastis-untuk-meliberalkan-uuperkawinan/, diakses 2 Desember 2013)

d. Mendesakralisasi lembaga perkawinan 
Pernyataan ini disampaikan oleh Siti Nafidah melalui tulisannya yang dimuat di situs resmi MHTI. Berikut ini kutipan dari pernyataan tersebut:

Jika dicermati isi deklarasi dan konvensi ini, nyaris sama dengan berbagai kebijakan yang sudah diundangkan maupun yang masih berupa draft rancangan UU. Kesemuanya mengandung spirit pembebasan dari aturan Islam, termasuk merombak pola interaksi, peran, dan fungsi perempuan sebagaimana diajarkan Islam sekaligus menghapus kepemimpinan suami, yang berujung pada upaya mendesakralisasi lembaga perkawinan sekaligus membuka keran kebebasan atas nama kesetaraan dan HAM. Sebagai contoh, UU PKDRT yang mengkriminalisasi peran suami dalam mendidik istri atau anak atas nama penghapusan tindak kekerasan, sekaligus mempublikasikan persoalan-persoalan privat yang sebenarnya diberikan solusinya oleh Islam. UU ini juga membuka celah terjadinya disfungsi dan disharmoni peran suami-isteri yang lebih jauh akan menggoyah keutuhan rumahtangga (Siti Nafidah, http://hizbuttahrir.or.id/2010/01/18/mewaspadai-upayaliberalisasi-keluarga-melalui-ide-gender/, diakses tanggal 26 Nopember 2013).

e. Menjauhkan muslimah dari cita-cita menjadi ibu

Pernyataan ini juga disampaikan Siti Nadifah dalam artikelnya sebagaimana disebut di atas. Berikut ini kutipannya.

Itulah kenapa, mereka sungguh-sungguh berupaya menghancurkan keluarga muslim dengan berbagai cara. Di antaranya, dengan berupaya menjauhkan para muslimah dari citacita menjadi ibu atau dari penyempurnaan peran $i b u$. Secara sistematis, diciptakanlah kemiskinan struktural melalui penerapan sistem ekonomi kapitalis yang memaksa para ibu bekerja untuk menutupi kebutuhan keluarga dan karenanya peran ibu tidak bisa optimal. Selain itu, mereka racuni benak para muslimah dengan berbagai pemikiran yang merusak semisal ide emansipasi atau keadilan dan kesetaraan gender dan kebebasan, sehingga para muslimah lebih tertarik mengaktualisasikan diridiranah publikdan pada saat yang sama merasa rendah diri akan peranperan domestik mereka. Dampak lanjutannya, lahir generasi tanpa bimbingan dan pengasuhan optimal para ibu (Siti Nafidah, http://hizbuttahrir.or.id/2010/01/18/mewaspadai-upayaliberalisasi-keluarga-melalui-ide-gender/, diakses tanggal 26 Nopember 2013). f. Memotivasi perempuan untuk berani melawan suami dan berani bercerai

Misalnya dapat terbaca dari pernyataan berikut ini:

pasca kegagalan mengusung Counter Legal Draft Kompilasi Hukum Islam (CLDKHI) yang dimotori feminis Musdah Mulia. CLDKHI memang secara terang-terangan dan frontal menyerang Islam, karena itu langsung dianulir.

Namun, para penggagas CLDKHI tak kurang akal. Mereka berupaya memasukkan substansisubstansi CLDKHI dalam peraturan perundangundangan yang lain. Di antaranya berhasil diloloskan menjadi hukum positif, seperti UU Penghapusan Kekerasan Dalam Rumah Tangga (UU PKDRT) yang berhasil memotivasi kaum perempuan untuk berani melawan suami dan berani bercerai (Siti Nafidah, http://hizbuttahrir.or.id/2010/01/18/mewaspadai-upayaliberalisasi-keluarga-melalui-ide-gender/, diakses tanggal 26 Nopember 2013).

g. Merupakan upaya konspirasi asing

Mengenai hal ini, banyak sekali pernyataan telah dilontarkan misalnya:

Lahirlah berbagai UU sekuler yang pro liberal di negeri-negeri tersebut dengan bantuan sponsorship para kapitalis (TAF, USAID, World Bank, dll) dan advokasi dari mereka. Di Indonesia sendiri, lahir UU PKDRT, UU Perlindungan Anak, UU Kewarganegaraan, UU Pornografi, draft CLD KHI, Rancangan Amandemen UU Perkawinan, Kesehatan Reproduksi dan Hukum Materil Peradilan Agama, yang kesemuanya mengandung ruh dan conten (isi) yang sama persis dengan 'kitab suci' yang diwahyukan musuh Islam tadi.

Apa yang menjadi tujuan semua konspirasi mereka sesungguhnya sangat jelas, yakni ingin merusak identitas keislaman kaum muslimin, menghapus militansi ideologis mereka dan melemahkan dayajuang umat Islam. Dengan cara ini, target besar mereka akan terwujud, yakni menghambat gerakan mengembalikan Khilafah Islamiyah yang memang sudah menggejala di seluruh dunia. Terlebih, sebagaimana prediksi RAND Corporation (lembaga intelejen AS), ada kemungkinan pada tahun 2020 peta politikglobal disemarakkan dengan bangkitnya kekhilafahan baru. Karenanya, AS sebagai motor kapitalisme global sedini mungkin berupaya memperkecil 
kemungkinan tersebut dengan berbagai cara (Siti Nafidah,http://hizbut-tahrir.or.id/2010/01/18/ mewaspadai-upaya-liberalisasi-keluargamelalui-ide-gender/. diakses tanggal 26 Nopember 2013).

2. Representasi MHTI terhadap Penggagas Amandemen Undang-Undang terkait Perempuan dan Keluarga

Ada beberapa istilah yang digunakan MHTI dalam menyebut pihak-pihak yang menggagas amandemen undang-undang terkait perempuan dan keluarga. Istilah-istilah yang digunakan adalah:

\section{a. Komprador}

Istilah ini disebutkan dalam booklet HTI untuk menyebut phak-pihak yang berupaya melakukan perubahan terhadap undang-undang terkait perempuan dan keluarga. Berikut ini salah satu pernyataan yang menggunakan istilah tersebut:

Diakui atau tidak, serangan massif anti-syariah, yang jelas-jelas anti Islam itu sebenarnya adalah bagian dari upaya negara-negara kafir Imperialis untuk memerangi Islam dan kaum muslim. Melalui para komprador yang bercokol di negeri ini, mereka menebarkan racun yang dikemas dengan lidah. Dengan klaim membela perempuan, HAM, kesetaraan gender dan istilah-istilah simpatik lainnya (Hizbut Tahrir Indonesia; 2006, 17).

b. Musuh Islam

Hizbut Tahrir mendefinisikan orang-orang yang turut menyuarakan perubahan terhadap undang-undang perkawinan sebagai bagian dari musuh Islam karena menjalankan agenda dari musuh Islam, yaitu para kapitalis Barat.

Lahirlah berbagai UU sekuler yang pro liberal di negeri-negeri tersebut dengan bantuan sponsorship para kapitalis (TAF, USAID, World Bank, dll) dan advokasi dari mereka. Di Indonesia sendiri, lahir UU PKDRT, UU Perlindungan Anak, UU Kewarganegaraan, UU Pornografi, draft CLD KHI, Rancangan Amandemen UU Perkawinan, Kesehatan Reproduksi dan Hukum Materil Peradilan Agama, yang kesemuanya mengandung ruh dan conten (isi) yang sama persis dengan 'kitab suci' yang diwahyukan musuh Islam tadi (Hizbut Tahrir Indonesia, 2006: 17). c. Perpanjangan tangan negara kafir Imperialis

Misalnya terlihat dari pernyataan:

Ketika umat menolak liberalisasi yang terkandung dalam CLD-KHI, tanpa disadari mereka digiring untuk menerima secara bertahap proses liberalisasi ini melalui berbagai UU yang berwajah liberal. Ini jelas merupakan langkah penuh tipu daya yang bertujuan merusak Islam dan kaum muslim di tengah keluarga dan masyarakat. Ide keadilan dan kesetaraan gender (KKG) telah menggelobal di bawah Perserikatan Bangsa-Bangsa sebagai perpanjangan tangan negara-negara kafir imperialis (Hizbut Tahrir Indonesia, 2006: 12).

\section{Analisis atas Teks Respon MHTI Terhadap Undang-Undang dan Rancangan Undang- Undang Terkait Perempuan dan Keluarga}

Dari semua teks yang digunakan Muslimah Hizbut Tahrir dalam merespon upaya perubahan terhadap undang-undang yang terkait perempuan dan keluarga yang dalam hal ini adalah RUU HMPA, CLD-KHI dan UU PKDRT, tema yang diangkat dalam setiap wacana menampilkan penegasan Hizbut Tahrir akan adanya upaya-upaya pihak asing untuk mengahapuskan hukum keluarga di negara Muslim, karena hanya hukum keluargalah yang tersisa dari hukum Islam yang masih tetap diberlakukan di beberapa negara muslim. Sementara hukum-hukum yang lain seperti hukum pidana dan perdata umum sudah banyak mengadopsi hukum dari negara-negara Barat.

Penegasan adanya intervensi asing tersebut menjiwai setiap artikel yang ditulis Muslimah Hizbut Tahrir maupun pemberitaan yang ada. Dari segi struktur makro wacana yang digulirkan Hizbut Tahrir, terkesan sama sekali tidak ada kompromi atau upaya netral untuk melihat hal lain yang bisa dinilai positif dari upaya perubahan itu. Struktur makro yang demikian itu terlihat dari bagaimana judul dipilih dalam tulisan-tulisan yang ada di situs resminya maupun di booklet-booklet yang disebarkan. Misalnya, ketegasan akan intervensi Barat ini terlihat dari beberapa judul berikut:

1. Skenario Penghancuran Bangsa dan Negeri Islam Melalui Liberalisasi Keluarga

2. Membangun Ketahanan Bersama Hadapi Liberalisasi-Pertarungan Ideologi dalam Keluarga Muslim

3. Menguak Racun di balik Madu Agenda Gender

4. Mewaspadai Upaya Liberalisasi Keluarga Melalui 


\section{Ide Gender}

5. Penghancuran keluarga melalui amandemen UU Perkawinan

Dalam struktur supra-wacana (superstructure), struktur wacana yang digulirkan Hizbut Tahrir dalam merespon upaya perubahan undang-undang terkait perempuan dan keluarga tersebut sangat khas. Biasanya, persoalan yang dibahas pertama adalah upaya-upaya atau agenda-agenda yang dinilai sebagai agenda kafir dengan memaparkan skenario Barat serta konsep-konsep yang mereka pandang bertentangan dengan konsep-konsep Islam. Setelah membeberkan skenario Barat serta mencocokkan konsep-konsep perubahan undang-undang terkait perempuan dan keluarga tersebut dengan skenario Barat, MHTI kemudian menawarkan solusi yang mereka istilahkan dengan solusi Islam atas problematika bangsa. Dalam menawarkan solusi ini, dibahas konsep-konsep dasar Hizbut Tahrir tentang perempuan dan keluarga, tentang relasi suami istri, serta tentang pergaulan di masyarakat yang kemudian diakhiri dengan seruan untuk mencampakkan ide-ide yang berasal dari Barat tersebut.

Pendapat Syaikh Taqiyuddin an-Nabhani selalu dikutip dalam setiap artikel maupun pemberitaan tentang upaya amandemen undangundang terkait perempuan dan keluarga. Berikut ini adalah salah satu pendapat yang sering dikutip:

\section{liberalisasi dan pemberdayaan perempuan (women liberalization and empowerment of women) adalah salah satu cara Barat yang dikomandoi AS untuk menyebarkan ide kapitalis agar mereka bisa menjajah negeri-negeri muslim. Mereka sengaja merusak akidah Islam, merobohkan sendi-sendi hukum Islam serta mengatur pemikiran dan perilaku umat agar mengikuti keinginan mereka ("UU Perkawinan, Mewaspadai Kaum Liberal", dalam http:// hizbut-tahrir.or.id/2011/10/28/uu-perkawinan- mewaspadai-kritik-kaum-liberal/).}

Bila dilihat dari struktur mikro wacana, latar yang dipilih oleh MHTI adalah penggambaran suasana kehidupan muslim yang selalu terintimidasi dengan semua upaya yang dilakukan pihak-pihak yang mereka istilahkan dengan kapitalis atau kafir Barat. Situasi intervensi dan intimidasi kafir Barat ini akan bisa diatasi dengan sempurna kalau umat Islam menerapkan syariah Islam sebagaimana konsep-konsep syariah Islam yang mereka tawarkan dalam berbagai bidang kehidupan. Semua persoalan akan selesai dengan khilafah, ini menjiwai setiap wacana yang digulirkan Hizbut Tahrir baik dalam struktur makro, supra, maupun mikro wacana. Baik dalam level teks, kognisi sosial, maupun konteks wacana yang digulirkan.

Apa yang dilakukan MHTI melalui wacana yang digulirkannya merupakan taktiktaktik kekuasaan yang menurut Michel Foucault terwujud dalam tiga taktik, yaitu taktik pemilahan (classification practice), taktik normalisasi (deviding practices), dan taktik pendisiplinan (panoptic). Melalui taktik pemilahan (classification practice), MHTI membuat logika dualistik yang mengklasifikasikan tindakan mengubah undangundang terkait perempuan dan keluarga ke dalam dua kutub yang saling berlawanan, yaitu: Barat kafir versus Islam, pemikiran Islam versus kapitalisimperialias, ideologi Islam versus idologi kafir, dan lain sebagainya (Michel Foucault,1971: 387).

Taktik normalisasi dinyatakan Foucault memiliki fungsi ganda, yaitu di samping mengukuhkan sistem kebenaran yang diakui sebagai normalitas, juga mengubur sistem kebenaran lain yang diasosiasikan sebagai abnormal yang dianggap bakal mengganggu ketertiban sistem berfikir dan berperilaku masyarakat. Dalam wacana respon MHTI terhadap undangundang terkait perempuan dan keluarga, terlihat secara sangat eksplisit bagaimana MHTI membuat wacana yang berusaha menjelaskan kebenaran ideologi Islam yang diyakininya dan mengubur ideologi gender yang diusung kaum feminis. Melalui serangkaian istilah yang digunakan MHTI untuk merepresentasikan perjuangan kaum feminis, sebagaimana dirinci di atas, MHTI ingin menegaskan bahwa keyakinannyalah yang benar dan normal menurut Islam, sementara keyakinan kaum feminis menyimpang dan tidak normal.

Taktik kekuasaan ketiga menurut Foucault adalah taktik pendisiplinan tubuh oleh kekuasaan menggunakan sistem biopower. Biopower adalah teknologi yang dikembangkan untuk menganalisis, menata, mendefinisikan tubuh dan perilaku manusia. Gagasan dasar biopower adalah menghasilkan subyek yang swa-kendali; sekali tubuh dan pikiran kita dibentuk, maka dengan sendirinya kita memastikan diri berfungsi sebagaimana didiktekan (Michel Foucault, 1977: 119). (Donny Gahral Adian, 2002: 45).

Logika biopower adalah logika panoptik, yaitu bentuk pengawasan yang tidak lagi membutuhkan kekerasan fisik yang membekas pada tubuh, tetapi melalui pengetahuan. Sistem ini memungkinkan 
pengawasan secara tidak teratur, tetapi memiliki efek perasaan terus-menerus diawasi dalam kesadaran; pengawasan dilakukan secara diskontinyu dengan efek yang kontinyu (Haryatmoko, 2002: 17).

Penanaman konsep bahwa Islamlah satusatunya jalan yang benar dan semua agenda yang berasal dari negara-negara Barat adalah berkeinginan menghancurkan Islam baik secara ekonomi, politik, maupun budaya ditanamkan oleh MHTI melalui wacana yang disampaikan dalam halaqah-halaqah yang diselenggarakan untuk anggota, melalui seminar-seminar, tulisan-tulisan di situs resmi mereka, booklet-booklet dan buku-buku tentang Hizbut Tahrir yang mereka terbitkan, dan lain sebagainya.

Ketika konsep-konsep HTI telah terinternalisasikan dengan baikkedalam dirimasingmasing anggota, melalui serangkaian pendidikan di atas, maka dapat dipastikan konsep-konsep tersebut akan dengan sendirinya dipraktekkan tanpa harus terus diperintah dan diawasi. Inilah yang dimaksud dengan kekuasaan oleh Michel Foucault. Kekuasaan tidak selalu berupa sesuatu yang negatif, seperti menindas, mengintimidasi, dan lain-lain, wajah kekuasaan yang canggih dan sempurna justru menghampiri melalui pengetahuan dengan cara yang positif dan produktif. Kekuasaan diterima dan ditaati bukan karena kekuatan memaksa yang dimilikinya, tetapi kemampuannya untuk tampil sebagai sesuatu yang indah dan mengesankan di mata mereka yang dikuasai. Kekuasaan seperti inilah yang dikembangkan MHTI untuk mengikat para anggotanya agar mengamalkan ajaran-ajaran yang sudah ditanamkan, serta mengajak masyarakat melalui pemaparan yang mengesankan tentang konsep-konsep mereka agar masyarakat mau bergabung dan menjadi bagian dari perjuangan MHTI.

\section{Kognisi Sosial Muslimah Hizbut Tahrir Indonesia sebagai Pembuat Teks}

Selain melakukan analisis terhadap teks seperti di atas, analisis wacana kritis juga mengkaji bagaimana kognisi sosial pembuat teks. Kognisi sosial merupakan kesadaran mental pembuat teks yang berupa kepercayaan, pengetahuan dan prasangkanya. Dalam sistem pengetahuan, kepercayaan, dan prasangka pembuat teks, terdapat skema/model yang digunakan pembuat teks dalam memandang orang lain (person schemas), dirinya sendiri (self schemas), peran (role schemas), serta peristiwa (event schemas).
Melihat bagaimana kognisi sosial MHTI sehingga menghasilkan teks wacana yang seperti dijelaskan dalam bab sebelumnya, meniscayakan pengkajian tentang bagaimana orang lain (person schemas), yaitu kaum feminis sebagai motor perubahan undang-undang terkait perempuan dan keluarga, didefinisikan oleh MHTI, serta bagaimana MHTI mendefinisikan dirinya sendiri berkenaan dengan sikap yang diambilnya dalam merespon undang-undang terkait perempuan dan keluarga (self schemas). Penting pula dilihat bagaimana MHTI memandang peran dan posisi perempuan menurut konsepsi MHTI (role schemas), serta bagaimana MHTI memandang adanya upaya untuk mengamandemen undang-undang terkait perempuan dan keluarga (event schemas).

Dalam menggambarkan apa yang dilakukan oleh aktifis feminis yang berupaya melakukan perubahan bidang hukum keluarga Islam di Indonesia, ada banyak istilah yang digunakan MHTI untuk menggambarkan dan mendefinisikan tindakan yang diambil oleh kaum feminis. Istilahistilah yang digunakan dalam wacana mereka, penulis catat, sebagai berikut ini:

a. Liberalisasi hukum Islam, liberalisasi ulama, liberalisasi bangsa

b. Menghancurkan keluarga dan masyarakat Islam

c. Menghapus sisa-sisa hukum Islam

d. Tipu daya yang merusak Islam dan masyarakat muslim

e. Merubah hukum Allah

f. Menjadikan fakta sebagai sumber hukum Islam

g. Menggugat pelaksanaan syariah

h. Pembebasan dari aturan Islam

i. Menghapus kepemimpinan suami

j. Mendesakralisasi lembaga perkawinan

k. Mengkriminalisasi peran suami dalam mendidik istri dan anak

1. Membuka celah terjadinya disfungsi dan disharmoni peran suami-istri

m. Menggoyang keutuhan rumah tangga

n. Menjauhkan muslimah dari cita-cita menjadi ibu

o. Meracuni pikiran muslimah dengan pemikiran yang merusak

p. Merusak identitas keislaman kaum muslim

q. Menghapus militansi ideologis dan melemahkan daya juang umat

r. Menghambat gerakan mengembalikan khilafahislamiyah

Istilah-istilah yang digunakan untuk menggambarkan aktifitas feminis dalam melakukan 
perubahan terhadap undang-undang terkait perempuan dan keluarga seperti di atas, bukan hanya berdampak terhadap pencitraan negatif gerakan feminis di mata anggota MHTI sendiri dan masyarakat luas, tetapi juga menjadi strategi wacana MHTI agar masyarakat tidak mengikuti faham keadilan dan kesetaraan gender yang diusung aktifis feminis atau agar meninggalkan faham tersebut. Menampilkan istilah-istilah tersebut dalam berwacana juga menjadi bagian dari strategi MHTI untuk menjaga kelestarian konsep-konsepnya di hadapan anggota-anggotanya sendiri maupun masyarakat secara umum.

Dalam memandang dirinya (self schemas), MHTI merepresentasikan dirinya sebagai khairuummah, yaitu masyarakat terbaik yang diperintah Allah untuk menyeru kebaikan dan menolak kemungkaran. Ini menjadi motto gerakan yang dilakukan HTI sesuai dengan Q.S. Ali Imran: 104 (“Tentang Kami”, dalam http://hizbut-tahrir. or.id/tentang-kami/, diakses 2 Desember 2013). Mereka juga menamakan dirinya dengan kelompok yang bermaksud membangkitkan kembali umat dari kemerosotan yang amat parah, membebaskan umat dari ide-ide, sistem perundang-undangan dan hukum-hukum kufur, dan membebaskan dari cengkraman dominasi dan pengaruh negara-negara kafir untuk membangun kembali daulah khilafah Islamiyah di muka bumi ("Tentang Kami", dalam http://hizbut-tahrir.or.id/tentang-kami/, diakses 2 Desember 2013).

Dalam memandang peran dan posisi perempuan (role schemas), MHTI memilki konsep tersendiri yang khas yang dijelaskan dalam bab sebelumnya. Perempuan menurut MHTI memiliki tugas utama sebagai istri dan ibu yang berkewajiban mengurus rumah tangga, mendidik dan mengasuh anak-anak. Meskipun demikian bukan berarti perempuan tidak boleh bekerja atau berprofesi di luar rumah, mereka tetap bisa bekerja jika yakin pekerjaan itu tidak akan mengganggu tugas utama mereka sebagai istri dan ibu (http://hizbut-tahrir. or.id/2009/04/21/peran-penting-perempuanmencetak-generasi-ideologis/. Diakses 2 Desember 2013). Mereka bisa menjadi dokter, pegawai negeri, guru dan lain sebagainya. Namun, ada posisi yang haram untuk diberikan kepada kaum perempuan, yaitu sebagai pemimpin atau penguasa. Mengangkat perempuan menjadi kepala negara dihukumi MHTI dengan hukum haram. Penegasan ini dilakukan MHTI karena telah ada hadis yang tegas bahwa tidak akan beruntung suatu kaum yang menyerahkan urusannya kepada kaum perempuan. Hadis ini juga dikuatkan dengan pendapat empat mazhab yang menyatakan keharaman yang sama (http://hizbuttahrir.or.id/2009/04/21/peran-penting-perempuanmencetak-generasi-ideologis/. Diakses 2 Desember 2013).

Laki-laki dan perempuan menurut MHTI memiliki posisi yang sama di hadapan Allah, dalam artian bahwa keduanya dapat memperoleh kedudukan yang mulia dengan berusaha melaksanakan ketaatan. Meskipun demikian, keduanya memiliki kewajiban yang berbeda karena secara fisik diciptakan Allah berbeda. Kewajiban memberi nafkah dipikul oleh suami, sementara kewajiban mengurus rumah menjadi tanggung jawab istri; suami berperan sebagai pemimpin, sementara istri berperan sebagai pendidik generasi dan pengelola rumah tangga.

MHTI juga memiliki skema tersendiri dalam memandang sepak terjang kaum feminis yang ingin melakukan perubahan terhadap undang-undang terkait perempuan dan keluarga (event schemas). MHTI memandang upaya perubahan undangundang terkait perempuan dan keluarga sebagai bagian dari agenda Internasional terhadap umat Islam melalui $\mathrm{PBB}$ atas pesanan negara-negara kapitalis.

Peristiwa yang menggambarkan upaya-upaya pemerintah maupun kaum feminis untuk merubah undang-undang terkait perempuan dan keluarga dinilai MHTI sebagai upaya terselubung liberalisasi keluarga dan penghancuran keluarga Islam dengan cara menggoyang terus-menerus tatanan keluarga Islam. Munculnya respon MHTI terhadap rancangan dan undang-undang terkait perempuan dan keluarga lahir dari kognisi sosial pembuat teks, baik dari kalangan HTI maupun MHTI yang memiliki skema tersendiri dalam memandang orang lain, dirinya sendiri, peran, serta peristiwa mengenai rancangan dan undang-undang terkait perempuan dan keluarga.

Bagaimana skema-skema dalam kognisi sosial MHTI itu terbentuk, menjadi pertanyaan berikutnya yang dijawab oleh Pierre Bourdieu dengan teori habitus. Habitus dapat dirumuskan sebagai sistem disposisi-disposisi (skema-skema persepsi, pikiran dan tindakan) yang diperoleh dan bertahan lama. Habitus juga merupakan gaya hidup (life style), nilai-nilai (values), watak (disposition), dan harapan kelompok sosial tertentu. Bourdieu menggunakan konsep ini dalam beberapa makna berikut: Pertama, habitus merupakan pengkondisian yang dikaitkan dengan keberadaan suatu kelas. Keseragaman habitus dalam suatu kelompok menjadi dasar 
perbedaan gaya hidup dalam suatu masyarakat. Gaya hidup dipahami sebagai keseluruhan selera, kepercayaan dan praktik sistematis yang menjadi ciri suatu kelas. Termasuk ke dalam gaya hidup ini opini politik, keyakinan filosofis, keyakinan moral, selera estetis, juga makanan dan pakaian.

Kedua, habitus merupakan hasil keterampilan yang menjadi tindakan praktis yang tidak selalu disadari; menjadi suatu kemampuan yang terlihat alamiah. Habitus dihasilkan melalui pengalaman pengasuhan, aktivitas bermain, dan juga pendidikan masyarakat dalam arti luas. Pembelajaran itu terjadi secara halus, tak disadari dan tampil sebagai hal wajar sehingga seolah-olah sebagai sesuatu yang alamiah, seakan-akan terberi oleh alam dan sudah dari sananya. Dari makna ini, habitus menjadi struktur yang menstrukturkan (structuring structure), yaitu struktur yang menghasilkan dunia sosial. Habitus sekaligus menjadi struktur yang terstrukturkan (structured structure), yaitu struktur yang dihasilkan oleh dunia sosial. Dengan istilah lain Bourdieu menggambarkan habitus sebagai dialektika internalisasi eksternalitas dan eksternalisasi internalitas (Pierre Bourdieu, 1977: 71).

Ketiga, habitus adalah kerangka penafsiran untuk memahami dan menilai realitas sekaligus penghasil praktik-praktik kehidupan yang sesuai dengan struktur-struktur objektif. habitus berasal dari proses dua gerak timbal-balik, yaitu pembatinan struktur obyektif dan gerak subyektif yang berupa persepsi, pengelompokan, evaluasi yang menyingkapkan hasil pembatinan. Kedua gerak timbal-balik ini dapat dilihat dalam proses sosialisasi yang membuat individu membuka dan melatih diri dalam hubungan-hubungan sosial, mengasimilasi norma, nilai-nilai dan keyakinan suatu masyarakat.

Keempat, habitus menyangkut nilai-nilai yang dipraktekkan, bentuk moral yang diinternalisasikan dan tidak mengemuka dalam kesadaran namun mengatur perilaku sehari-hari tetapi bukan etika, misalnya seperti sifat rajin, ulet, jujur, licik, cerdas, murah hati. Habitus juga berarti posisi khas tubuh yang secara tidak sadar diinternalisasikan sepanjang hidup misalnya berjalan tegak, mudah bergaul, cara duduk dengan merapatkan kedua kaki bagi perempuan, cara berbicara, cara makan dan lainlain (Haryatmoko, 2002: 5).

Kelima, Habitus merupakan struktur intern yang selalu dalam proses restrukturasi. Meskipun habitus merupakan struktur internal yang memberi pilihan tindakan tetapi habitus tidak menjadi determinan tindakan. Habitus sekedar menyarankan apa yang seharusnya dipikirkan orang dan apa yang seharusnya dipilih untuk dilakukan. Aktor tidaklah dungu (bertindak tanpa pertimbangan rasional) dan tidak pula sepenuhnya rasional. Aktor bertindak menurut logika arena pertarungan dan sesuai dengan posisinya dalam ruang sosial (George Ritzer dan Douglas J. Goodman, 2011: 582).

Wacana yang digulirkan MHTI tidak bisa dilepaskan dari habitus MHTI sendiri. Habitus ini terbentuk melalui serangkaian pendidikan yang diselenggarakan oleh MHTI untuk para anggotanya. MHTI menggunakan beberapa metode dakwah. Metode pertama yang dijalankan adalah pembentukan gerakan, yaitu tahapan pembentukan halaqah pertama yang dikenalkan dengan konsepkonsep dasar Hizbut Tahrirserta metode dakwahnya. Halaqah pertama ini kemudian menghubungi anggota masyarakat lainnya untuk menawarkan konsep-konsep serta metode dakwah Hizbut Tahrir tersebut. Mereka yang menerima konsep dan metode dakwah Hizbut Tahrir akan dibina secara intensif sampai mereka memiliki kepribadian, yang disebut Hizbut Tahrir dengan syakhsiyah Islamiyah, sampai mereka berfikir dan memandang segala sesuatu dari kerangka yang telah diberikan pada mereka dalam proses penggemblengan tersebut. Dari sini kemudian akan terbentuk apa yang mereka istilahkan dengan nafsiyah Islamiyah, atau jiwa dan pola pikir islami. Ketika nafsiyah Islamiyah telah terbentuk, seseorang akan tetap mengikuti Islam walau kemana pun ia melangkah. Dalam keadaan ini, sesorang akan mengharuskan dirinya bergabung dan menyatu dengan Hizbut Tahrir. Metode dakwah seperti inilah yang juga dilakukan Rasulullah dalam menyebarkan Islam pertama kali, yaitu metode dakwah secara rahasia (http://hizbuttahrir.or.id/2013/08/13/tahapan-dakwah-danaktivitas-politik-hizbut-tahrir/, diakses 2 Desember 2013).

Metode pertama ini menjadi media penting dalam proses inisiasi keanggotaan MHTI. Karena dari sinilah skema-skema yang menjadi visi organisasi diinternalisasikan ke dalam diri masingmasing anggota sehingga menjadi skema-skema diri mereka, menjadi kerangka berfikir yang mereka gunakan dalam menafsirkan realitas, termasuk di dalamnya dalam memberi respon terhadap rancangan dan undang-undang terkait perempuan 
dan keluarga. Ketika apa yang diistilahkan MHTI dengan nafsiyah Islamiyah terbentuk, maka ini lah habitus yang dimaksudkan oleh Pierre Bourdieu itu.

\section{Analisis Konteks Sosial Respon Muslimah Hizbut Tahrir Indonesia terhadap RUU HMPA, CLD- KHI dan UU PKDRT}

Lahirnya HTI, dilatarbelakangi oleh keprihatinan akan kemunduran umat Islam, baik dari segi kehidupan ekonomi, sosial, politik, maupun budaya. Padahal jauh sebelumnya, umat Islam telah mencapai kejayaan yang luar biasa di saat masyarakat Eropa sedang tenggelam dalam kegelapan. Menurut teori yang diajukan Hizbut Tahrir, kemunduran di segala lini kehidupan umat ini dikarenakan meninggalkan ajaran Islam dengan menjadikan negara-negara Barat sebagai acuan, baik di bidang ekonomi, sosial, politik maupun kebudayaan. Kondisi umat Islam jauh lebih baik saat masih berada dalam sistem khilafat dan ketika sistem ini runtuh di tangan Mustafa Kemal dibawah jajahan Inggris, satu demi satu negara-negara Islam berdiri sendiri dan terpecah belah. Dalam keadaan terpecah belah inilah penjajah Barat masuk, tidak hanya secara fisik tetapi juga mewarnai dan menentukan pola pikir dan kebudayaan negaranegara Islam yang menjadi jajahannya.

Solusi yang ditawarkan HTI kemudian adalah, mengembalikan negara-negara Islam yang telah terpecah belah itu ke dalam satu panji khilafat sebagaimana pada masa lalu sistem ini diterapkan. Di samping berjuang menegakkan Islam secara kaffat dalam setiap aktivitas, baik itu aktivitas politik, ibadah, keluarga, bermasyarakat dan lain sebagainya, Hizbut Tahrir juga melakukan perjuangan melawan upaya-upaya kolonialisasi Barat terhadap negara-negara Islam dalam berbagai bentuknya. Penjajahan saat ini mungkin tidak lagi dilakukan secara fisik, tetapi justru lebih dalam dari itu, penjajahan masuk melalui jalan-jalan yang bisa mengubah umat untuk meninggalkan ajaran agama Islam, misalnya melalui perundang-undangan.

Dengan latar belakang tersebut, Hizbut Tahrir kemudian mencanangkan metode dakwah yang mereka istilahkan dengan Ash-Shira' al-Fikri (Pergolakan Pemikiran) untuk menentang ideologi, peraturan-peraturan dan ide-ide kufur, selain untuk menentang akidah yang rusak, ide-ide yang sesat dan pemahaman-pemahaman yang rancu. Aktivitas ini dilakukan dengan cara menjelaskan kepalsuan, kekeliruan dan kontradiksi ide-ide tersebut dengan Islam. Adapula metode dakwah yang mereka istilahkan dengan Al-Kifaah Al-Siyasi (Perjuangan Politik) yang mencakup aktivitas-aktivitas: berjuang menghadapi negara-negara kafir imperialis yang menguasai atau mendominasi negeri-negeri Islam, menentang para penguasa di negaranegara Arab maupun negeri-negeri Islam lainnya; mengungkapkan (rencana) kejahatan mereka; menyampaikan nasihat dan kritik kepada mereka.

Dengan latar belakang seperti inilah, maka lalu MHTI memunculkan wacana kritik terhadap rancangan dan undang-undang terkait perempuan dan keluarga yang menurut mereka merupakan bagian dari agenda terselubung imperialisme Barat terhadap umat Islam agar meninggalkan ajaran agama Islam. Teori-teori yang diajukan HTI dalam menyelesaikan masalah kemunduran umat Islam tersebut menjadi sistem pengetahuan yang bersarang dalam struktur pikir mereka.

Untuk dapat terus menghidupkan dan mengembangkan visi di tengah banyaknya organisasi-organisasi perempuan yang mempunyai visi bertentangan dengan visinya, MHTI berusaha mengumpulkan banyak modal agar dapat menandingi organisasi-organisasi perempuan tersebut dan agar bisa eksis di tengah-tengah persaingan ideologi. Dilihat dari perspektif Pierre Bourdieu, MHTI mengembangkan modal sosial yang makin lama makin besar. Modal sosial ini berupa jaringan keanggotaan yang bersifat internasional. Modal sosial yang sangat besar untuk sebuah organisasi independen seperti MHTI akan memudahkannya dalam mengakumulasi modalmodal lainnya seperti modal ekonomi, budaya dan simbolik. Semakin banyak komposisi modal yang dimiliki oraganisasi ini, maka akan semakin kuat posisinya di tengah arena pertarungan ideologi di Indonesia terutama di antara ideologi-ideologi gerakan perempuan lainnya.

\section{PENUTUP}

Terhadap rancangan dan undang-undang terkait perempuan dan keluarga, yang terfokus dalam penelitian ini pada RUU HMPA, CLD-KHI, dan UU PKDRT, Muslimah Hizbut Tahrir Indonesia menolak dengan tegas apa yang dilakukan oleh pemerintah dan aktifis-aktifis gender tersebut. Respon yang berupa penolakan ini secara tegas disuarakan Muslimah Hizbut Tahrir melalui berbagai media, seperti situs resmi mereka dalam http://hizbut-tahrir.or.id/. Maupun dalam bookletbooklet yang mereka sebarkan kepada anggota MHTI dan masyarakat umum. Penolakan tersebut 
juga dinyatakan MHTI dengan mengadakan kajian mengundang tokoh-tokoh yang berkompeten seperti Neng Djubaedah yang kemudian diliput dalam berita di situs resmi mereka. Dalam beberapa artkel yang ditulis aktifis MHTI juga dinyatakan dengan tegas penolakan terhadap RUU HMPA, CLD-KHI, maupun kritik pedas terhadap UU PKDRT.

Mereka menolak dengan beberapa alasan, bahwa apa yang dilakukan oleh aktifis perempuan yang mengusung ide keadilan dan kesetaraan gender merupakan sebentuk liberalisasi hukum Islam, liberalisasi ulama, liberalisasi bangsa, menghancurkan keluarga dan masyarakat Islam, menghapus sisa-sisa hukum Islam, tipu daya yang merusak Islam dan masyarakat muslim, mengubah hukum Allah, menjadikan fakta sebagai sumber hukum Islam, menggugat pelaksanaan syariah, pembebasan dari aturan Islam, menghapus kepemimpinan suami, mendesakralisasi lembaga perkawinan, mengkriminalisasi peran suami dalam mendidik istri dan anak, membuka celah terjadinya disfungsi dan disharmoni peran suami-istri, menggoyang keutuhan rumah tangga, menjauhkan muslimah dari cita-cita menjadi ibu, meracuni pikiran muslimah dengan pemikiran yang merusak, merusak identitas keislaman kaum muslim, menghapus militansi ideologis dan melemahkan daya juang umat, dan menghambat gerakan mengembalikan khilafah Islamiyah.

Dari sudut pandang analisis wacana kritis, apa yang dilakukan MHTI dalam menolak upaya-upaya yang dilakukan oleh aktifis feminis dalam mengamandemen undang-undang terkait perempuan dan keluarga, merupakan bagian dari pertarungan wacana yang melibatkan praktik kekuasaan. Strategi kekuasaan yang digunakan dalam wacana MHTI dapat terlihat dari level teks, kognisi sosial dan konteks. Dalam level teks, strategi wacana itu dilibatkan MHTI dalam struktur makro, yaitu pemilihan tema yang langsung menegaskan adanya upaya liberalisasi keluarga dalam proses amandemen undang-undang terkait perempuan dan keluarga. Dalam supra struktur teks serta mikro strukturnya menunjukkan adanya pemilihan istilahistilah tertentu utnuk merepresentasikan upayaupya yang dilakukan oleh aktifis feminis. MHTI juga menyebut aktifis feminis dengan istilah-istilah tertentu yang memperburuk citra mereka seperti istilah; komprador, bagian dari musuh Islam, serta kepanjangan tangan kafir imperialis.

Dilihat dari perspektif Michel Foucault tentang taktik kekuasaan, MHTI menjalankan ketiga taktik kekuasaan yang disebutkan Foucault, yaitu taktik pemilahan (classification practice) dengan membuat oposisi biner antara Barat vs Islam, pemikiran Islam vs kapitalis-imperialis, dan lain sebagainya. Taktik normalisasi digunakan MHTI untuk menggambarkan bahwa keyakinan MHTI yang normal dan benar sementara keyakinan aktifis feminis bukan keyakinan yang benar dan normal. Taktik pendisiplinan atau panoptic digunakan agar semua anggota dan masyarakat luas dengan sendirinya mematuhi dan berfikir sebagaimana yang didiektekan melalui wacana tersebut.

Ketiga taktik kekuasaan menurut Foucault tersebut senada dengan mekanisme sensorisasi dan eufimisasi dalam teori Bourdieu tentang kekerasan simbolik. Melalui wacana yang digulirkannya, khalayak digiring untuk meyakini bahwa sistem khilafah adalah satu-satu sistem yang bisa mengatasi segala persoalan bangsa dan satu-satunya sistem yang absah menurut Islam. Melalui mekanisme sensorisasi MHTI membenturkan konsep-konsep keislamannya dengan konsep-konsep aktifis gender yang menurutnya berasal dari konsep kapitalis Barat yang memiliki agenda terselubung untuk menghancurkan umat Islam.

Munculnya teks wacana berupa respon MHTI tersebut dapat dilihat sebab-sebabnya dengan mengkaji kognisi sosial serta konteks sosial MHTI, bagaimana skema-skema yang digunakan MHTI dalam memandang orang lain, diri sendiri, peran dan peristiwa, serta bagaimana latar belakang pergerakan mereka akan sangat mempengaruhi wacana-wacana yang mereka gagas.

\section{UCAPAN TERIMA KASIH}

Penulis mengucapkan banyak-banyak terima kasih kepada: Bapak Rektor UIN Sunan Ampel Surabaya yang telah memberikan kesempatan dan izin kepada penulis untuk melakukan penelitian. Bapak. Dr. H. Fatoni Hasyim, M.Ag, selaku Kepala Lembaga Penelitian dan Pengabdian Masyarakat (LPPM) UIN Sunan Ampel Surabaya yang telah memberikan kepercayaan dan kemudahan kepada kami selama proses penelitian berlangsung. Bapak Dr. Abd. Chalik, M.Ag selaku kepala Puslitbit LPPM UIN Sunan Ampel yang telah meloloskan usulan penelitian ini. Secara khusus, teriring ucapan terima kasih pada pengelola Jurnal al-Qalam, Balitbang Agama Makassar yang telah bersedia memuat artikel ini. 


\section{DAFTAR PUSTAKA}

Adian, Donny Gahral. 2002. "Menabur Kuasa, Menuai Wacana," dalam Basis, No. 01-02, Tahun ke 51, Januari-Februari.

Arifin, Syamsul. 2005. Ideologi dan Praksis Gerakan Sosial Kaum Fundamentalis: Pengalaman Hizb al Tahrir Indonesia. Malang: UMM Press.

Haryatmoko. "Kekuasaan-Pengetahuan sebagai Rezim Wacana, Sejarah Seksualitas: Sejarah Pewacanaan Seks dan Kekuasaan Menurut Foucault," Makalah Seri Kuliah Umum "Tentang Seksualitas", diterbitkan di www. salihara.org.

--------, "Habitus dan Kapital dalam Strategi Kekuasaan, Teori Strukturasi Pierre Bourdieu dengan Orientasi Budaya," Makalah tidak diterbitkan dipresentasikan dalam rangkaian pelatihan analisis sosial budaya Unit Kebudayaan Jawa Timur (UK2JT) Fakultas Ilmu Budaya Universitas Airlangga Surabaya tanggal 04 April 2012.

Isnaeniah, Erni. 2009. Gerakan Tandingan Feminisme, Tinjauan Terhadap Respon Muslimat Hizbut Tahrir Indonesia (HTI) Kota Bandung, penelitian individual tidak diterbitkan. Bandung: Lembaga Penelitian IAIN Sunan Gunung Jati.

Kholis, M. Anas. 2007. Regulasi Poligami dalam Undang-Undang RI No.1/1974 dan Kompilasi Hukum Islam: Studi Konstruksi Sosial Muslimah Hizbut Tahrir Indonesia. Skripsi tidak diterbitkan. Malang: Universitas Islam Negeri Maulana Malik Ibrahim.

Pierre, Bourdieu. 1977, Outline of a Theory of Practice. London: Cambridge University.

Ritzer, George dan Douglas J. Goodman. 2011. Teori Sosiologi Modern: Dari Sosiologi Klasik sampai Perkembangan Mutakhir Teori Sosial Posmodern. diterj. Nurhadi, Yogyakarta: Kreasi Wacana.

Sumbulah, Umi. 2007. "Islam Radikal" dan Pluralisme Agama: Studi Konstruksi Sosial Aktivis Hizbut Tahrir dan Majelis Mujahidin Indonesia di Malang tentang Agama Kristen dan Yahudi. Disertasi tidak diterbitkan, Surabaya: IAIN Sunan Ampel.

Van Dijk, Teun A. 2008. Discourse and Context A Sociocognitive Approach. New York: Cambridge University Press.

Van Dijk, Teun A. 2008. Discourse and Context
A Sociocognitive Approach, (New York: Cambridge University Press.

Foucault, Michel. 1971. Archeology of The Human Science. New York: Pantheon Books. , 1977. Power/Knowledge. New York: Pantheon Book.

http://hizbut-tahrir.or.id/2010/03/01/pandanganmuslimah-terhadap-nikah-siri/ diakses tanggal 30 Maret 2013.

http://hizbut-tahrir.or.id/2010/03/01/pandanganmuslimah-terhadap-nikah-siri/ diakses tanggal 30 Maret 2013.Teun A. van Dijk, 'Discourse Analysis as Ideology Analysis', dalam http://www.daneprairie.com.Diakses tanggal 13 Pebruari 2006.

http://hizbut-tahrir.or.id/2011/10/30/nikah-dinipenyebab-kdrt/ diakses tanggal 30 Maret 2013.

http://hizbut-tahrir.or.id/tentang-kami/ diakses tanggal 30 Maret 2013.

http://www.khabarmuslim.com/tag/nikah-siri diakses tanggal 30 Maret 2013.

Siti Nafidah, Keluarga Muslim dalam Ancaman (Mewaspadai Upaya Liberalisasi Keluarga Melalui Ide Gender)', dalam http://hizbuttahrir.or.id/2010/01/18/mewaspadai-upayaliberalisasi-keluarga-melalui-ide-gender/

Tahapan Dakwah dan Aktivitas Politik HizbutTahrirhttp://hizbut-tahrir.or.id/ 2013/08/13/tahapan-dakwah-dan-aktivitaspolitik-hizbut-tahrir/, diakses 2 Desember 2013.

Van Dijk Teun A., Discourse, Ideology and Context, dalam http://www.daneprairie.com diakses tanggal 13 Pebruari 2006.

Van Dijk, Teun A. 'Discourse Analysis as Ideology Analysis', dalam http://www.daneprairie.com. Diakses tanggal 13 Pebruari 2006.

"Ada Upaya Sistematis untuk Meliberalkan Hukum Perkawinan", dalam http://hizbut-tahrir. or.id/2009/04/06/ada-upaya-sistemastisuntuk-meliberalkan-uu-perkawinan/

"Mewaspadai Kritik Kaum Liberal", dalam http://hizbut-tahrir.or.id/2011/10/28/uuperkawinan-mewaspadai-kritik-kaumliberal/

"Peran Penting Perempuan Mencetak Generasi Ideologis, Wawancara Eksklusif dengan jubir MHTI Febrianti Abbasuni”, dalam http://hizbut-tahrir.or.id/2009/04/21/peranpenting-perempuan-mencetak-generasiideologis/. Diakses 2 Desember 2013. 
“Tentang Kami”, dalam http://hizbut-tahrir.or.id/ tentang-kami/, diakses 2 Desember 2013.

"UU Perkawinan, Mewaspadai Kaum Liberal", dalam http://hizbut-tahrir.or.id/2011/10/28/ uu-perkawinan-mewaspadai-kritik-kaumliberal/ 